This item was submitted to Loughborough's Research Repository by the author.

Items in Figshare are protected by copyright, with all rights reserved, unless otherwise indicated.

\title{
'You want the buzz of having done well in a game that wasn't easy': a sociological examination of the job commitment of English football referees
}

PLEASE CITE THE PUBLISHED VERSION

http://dx.doi.org/10.1051/sm/2014017

PUBLISHER

(C) ACAPS, EDP Sciences

VERSION

AM (Accepted Manuscript)

\section{PUBLISHER STATEMENT}

This work is made available according to the conditions of the Creative Commons Attribution-NonCommercialNoDerivatives 4.0 International (CC BY-NC-ND 4.0) licence. Full details of this licence are available at: https://creativecommons.org/licenses/by-nc-nd/4.0/

\section{LICENCE}

CC BY-NC-ND 4.0

\section{REPOSITORY RECORD}

Parsons, Tom, and Alan Bairner. 2019. “you Want the Buzz of Having Done Well in a Game That Wasn't Easy': A Sociological Examination of the Job Commitment of English Football Referees". figshare. https://hdl.handle.net/2134/17233. 


\title{
'You want the buzz of having done well in a game that wasn't easy': a sociological examination of the job commitment of English football referees.
}

\section{Tom Parsons (Loughborough University, UK)}

\author{
Alan Bairner (Loughborough University, UK) *
}

\begin{abstract}
Based on a critical reading of relevant literature and in-depth interviews with football referees from various levels of the game in England, the aim of this study is to understand why referees become involved and, more pertinently, why they remain committed to the role despite the abuse and disrespect which they regularly encounter. Having considered development of the football referee, the essay then examines existing literature concerned with refereeing as well as studies of job commitment in other human-service occupations. The subsequent data analysis leads to conclusions which both confirm and challenge findings of the limited research previously conducted in this area. Finally, the study suggests directions for organisations to follow in order to ensure the retention of referees.
\end{abstract}

Fondé sur une lecture critique de la littérature specialisée et des intervues avec les arbitres du football à tous les niveaux du jeu anglais, le but de cette étude est de comprendre pourquoi les arbitres deviennent - et, plus important, pourquoi ils restent - engagés malgré les insultes et le manque de respect qu'ils recncontrent regulièrement. Après l'analyse du development de l'arbitre, l'essai examine la littérature exististante sur l'occupation de l'arbitre et des autres professions qui exigent un contact humain similaire. Les résultats de l'analyse des données menent à des conclusions qui confirment et contestent les recherches limitées qu'on a fait 
jusqu’au présent. Finalement, l’étude aussi suggère les directions ouvertes aux organisations pour assurer qu’on continue de garder les services des arbitres.

Keywords: Football referees; football in England; job commitment; job satisfaction

\section{*Corresponding author A.E.S.Bairner@lboro.ac.uk}

\section{Introduction}

The football referee has been consistently ignored by academic researchers who write about the game and yet often serves as a focus of anger and even hatred for fans, players and club officials. Addressing this lacuna, the aim of this study is to understand why referees in England remain committed to the role despite the abuse and disrespect which they receive in the process.

The Football Association (FA) has long recognised that the retention of referees and ensuring their commitment have been problematic for many years (The Football Association, 2012). It has attempted to address these issues through the Respect campaign, launched in 2008 in response to a number of behavioural problems which were impacting upon the sustainability of referees' involvement in the game. The campaign was introduced with the primary objectives of recruiting and retaining enough referees to meet the demands of the game and reducing the number of assaults on referees (The Football Association, 2012). Statistical evidence suggests that it is currently achieving its objectives. 
One report shows that there was a $40 \%$ increase in the retention of new referees between 2008 and 2010 (Blanchard, 2010). In an earlier study, Pitchford (2005) suggested that 70\% of his respondents cited age as their reason for likely future withdrawal. An interesting age pattern of retention and recruitment is highlighted by both Blanchard (2010) and The FA (2012) as the number of referees aged between 14 and 19 rose by 23\% between 2007 and 2010, with over a quarter of the refereeing workforce now belonging to this age category. However, The FA has also encountered considerable difficulty in retaining referees between the ages of 20 and 24, with this age group experiencing a 579\% decrease between 2007 and 2010. To supplement current understanding of these issues, this study focuses on the following issues - job satisfaction and dissatisfaction, job commitment and involvement, personal ambition, financial incentives, and institutional and social support mechanisms.

One of the authors of this paper is currently on the middle rung of the refereeing ladder in England as a Level 4 referee operating at the semi-professional level of the game. This gave the authors access to referees from all levels of association football in England. The twelve participants involved in the study were aged between twenty-two and sixty-one and extended from a Premier League referee and Football League referee (Level One) and officials on the Panel list (Level Two) and Contributory Leagues list (Level Three and Four) to officials involved at the grassroots level of the game (Level Five) (See Appendix).

In addition to interviewing referees, we have also drawn on the limited existing literature on refereeing and on relevant research on job commitment in other professions. The following literature review consists of two sections: the emergence and development of the modern football referee and analysis of drop-out and involvement issues in a range of professions. 


\section{The genesis and development of the football referee}

The foundations of the game that would become football as it is known today were laid in Britain. In stark contrast to the world of calcio in Italy, the amateur, middle-class values that guided the game in England led to the belief that, under the auspices of the captains, teams could regulate themselves. Deliberate contravention of the rules by any player was unheard of at this time (Dunning and Sheard, 1979). However, the growing seriousness of the sport became the determining factor in public schools from 1847 recruiting the services of 'neutrals', primarily for important matches. These 'neutrals' were usually two umpires appointed by the opposing schools who patrolled opposite halves of the playing area. However, they lacked real authority as they were only consulted following agreement by the two captains (The Referees’ Association, 2012a).

The rule books of Cambridge and Sheffield during the 1850s and ultimately the unification of these codes with the formation of The FA in 1863 had a lasting impact on the game but failed to address the role of the official. Despite this, Thomson (1998) highlights the early influence of certain schools in this respect. Winchester School was one of the first to acknowledge the role of the official as all-encompassing: time-keeper, adjudicator and score-keeper. The rules from Cheltenham in 1849 were even closer to those for today's officials as a referee was introduced to replace the umpires as the final adjudicator. In addition, Harrow School claims to have been the first to give the power of the captains to the umpires (Thomson, 1998).

However, problems continued to plague the officials' control of the game. The neutrality of the adjudicator was consistently called into question. With an official rule-book not yet fully established, 'the (off-field) adjudicator was in no position to adjudicate' (Thomson, 1998, p.19). In addition, the growing professionalisation of the game increased the pressure on 
officials, leading from the 1880s to anger and abuse being directed at the officials (Mason, 1981).

The influential work of Charles W. Alcock accelerated the process of resolving these issues. Joining The FA committee in 1866, Alcock set about devising and redrafting the rules with an emphasis on officiating (Booth, 2002). In 1885, under Alcock's guidance, The FA offered advice for the first time to match officials on the laws of the game (Elleray, 2004). At the same time, Alcock was fighting to remove the appeal system used by captains and, thereby, to assign sole power to the umpires. This was an ambition not universally realised until 1894 with many critics identifying as the main reason 'a lack of 'qualified', impartial officials' (Thomson, 1998, p.31). The changes that occurred between 1888 and 1891 were regarded as vital (Thomson, 1998). The first was the formation of the Football League in 1888, necessitating a standardised rule book by which referees could operate. The idea of refereeing teams as seen throughout the world today was established in 1891. The umpires relinquished their previous power which was now vested in the referee. The umpires were renamed linesmen in the same year. These developments did not come without problems as highlighted in an article published by The Referees’ Association (2012 b),

The neutral referee was disliked form the outset. Clubs did not like his absolute authority, preferring a mutual agreement between their umpires. Spectators disputed decisions and referees were even assaulted.

Both the visibility and status of referees were now on the rise. Referees became increasingly embedded as an established body, receiving protection from The FA and subsequently from FIFA which was formed in 1904 in Paris (FIFA, 2012). One consequence was the emergence of competition between referees. In England, J. R. Schumacher, a prominent member of the Referees' Association, initiated the 'class' system, a version of which is still in place today 
(Mangan and Hickey, 2008). This classification system categorised referees from Class Three, a lowly county official, to Class One, a senior referee (Thomson, 1998). Selection for games in the early 1900s was based on an 'unspoken hierarchy' which was seen to have 'introduced an element of competitiveness into the referees’ work place which had hitherto been lacking' (Thomson, 1998, p.48). The most recent version of this system was introduced for the 2001/02 season and extends from Level Ten, a non-active referee, to Level One, a national list referee (The Referees’ Association, 2012 b).

With the growing importance of games at the highest level, the call for the professionalisation of referees began to increase (Colwell, 2000). Many FA secretaries backed this idea, the first of them being Ted Crocker in the late 1970s (Thomson, 1998). Booth (2002) describes the professionalism of the referee in terms of 'preparation, training and attitude' (p.178). It was eventually realised in 2001 when Phillip Don, the first referees’ officer for the Premier League, formed a select group of 23 referees, of whom 22 were paid. The autobiographies of members of this group reveal a tendency to accept that the only quantifiable benefit of turning professional was enforced fitness as there was little evidence that decision-making would improve (Elleray, 2004; Winter, 2006; Poll, 2008). Elleray (2004) did not believe that the professionalisation of referees immediately enhanced the status of refereeing. Furthermore, it is important to note that these referees stopped refereeing at the highest level due to laws that stipulated compulsory retirement at the age of 48. However, since 2010, age discrimination laws have been introduced following tribunal rulings in the favour of four assistant referees ('Tribunal rules retired assistant referees were discriminated against', 2010). If officials can meet the physical and intellectual criteria, age is no longer a just cause However, the competitive and hierarchical nature of refereeing has continued to grow alongside football’s commercialisation, with increased media exposure and financial pressures (Boon, 1998; 1999) resulting in a greater focus on referees’ mistakes. 


\section{Occupational turnover, involvement and degrees of job satisfaction: an overview}

Due to the existence of only one qualitative research study into continued involvement in refereeing (Pitchford, 2005), we have been obliged to examine research into non-sport occupations with specific reference to retention and turnover. This examination was restricted to professions that are human service based (Mor Barak et al, 2001) and are arguably most similar to that of refereeing, with a focus on concepts such as job satisfaction (Locke, 1976) and dissatisfaction (Vroom, 1964; Cheloha and Farr, 1980) as well as job involvement (Steers and Black, 1994) and job commitment (Mowday et al., 1979; Cooper-Hakim and Viswesvaran, 2005). Developing a better understanding of these related concepts enables comparisons to be made with the limited number of sources that shed light on refereeing turnover and, thereafter, with our own interview data.

Definitions of job satisfaction are mainly to be found in social psychological research. Locke (1976) describes it as a pleasurable or positive emotional state that derives from the perception that one's job is fulfilling or valued as important. Atkinson (1958) found that satisfaction is the consequence of successful performance which in turn affects turnover (Jackofsky, 1984).

Early research on turnover by Hulin $(1966,1968)$ found that job dissatisfaction and turnover were directly related and could also be linked to absenteeism (Vroom, 1964; Cheloha and Farr, 1980). An empirical study by Yucel (2012) subsequently found job satisfaction to be one of the most important antecedents of organisational commitment and turnover intention. For their part, Porter and Steers (1973) linked job satisfaction and withdrawal behaviour to four factors: organisation-wide; immediate work environment; job content; and personal circumstances all of which are evidenced in other non-sport studies that unearth specific 
micro-level dimensions of job dissatisfaction and motivation (Davis and Wilson, 2000; McCoy, 2003; Klassen and Anderson, 2009; Keigher, 2010; Rice et al., 2011). Finally, Harris and Adams (2007) argued that turnover patterns vary significantly by age group. Research by McCoy (2003) shows that teachers need greater respect, a higher salary, interested and involved students and parents, as well as active mentors for their own purposes. This is reinforced by Darling-Hammond (2003) who suggests that effective mentoring programmes can raise teacher retention rates by improving attitudes, feelings and instructional skills. Support for this within refereeing is offered in Pitchford's (2005) study with over $80 \%$ of respondents having no access to a mentor but approximately $75 \%$ believing that this could be valuable. External pressures on referees as highlighted earlier coincide with Bishay’s (1996) conclusions on teacher motivation research which suggest that future research should be directed towards examining the effects on teachers' morale of media reporting and outside perceptions. This is particularly relevant to refereeing with the dominant themes in a majority of the stories about referees being assault ('Chesham United match abandoned after striker punches referee', 2011) and abuse ('Rain of abuse stops play', 2005; 'Referee gets death threats over controversial Gerrard penalty', 2008; 'Assistant referee quits after abuse following Celtic row', 2010).

Pitchford's (2005) findings, however, dismiss the suggestion that a significant number of referees leave the game due to abuse and violence. More than half of his respondents reported dissatisfaction with the behaviour of spectators and more than a quarter reported dissatisfaction with player behaviour. Despite this, the combined effect of these issues on turnover intention was only $10 \%$. However, Pitchford's study did not examine those referees who had already dropped out. 
The concepts of job involvement and commitment explain the extent to which a person is interested in and committed to assigned tasks and how much of a responsibility s/he feels in ensuring the job is done correctly (Steers and Black, 1994). Saal and Knight (1995) consider the concept of job involvement to be anchored in attachment to the organisation as whole whilst Blau and Boal (1987) extend this to include the interaction between organisational commitment and job involvement as a predictor of turnover.

One way of uncovering the precise reasons for football referees remaining involved in the game is to look at evidence provided by referees who have enjoyed enough success to allow them to produce autobiographies. Of these, Taylor (1978) suggested that the enjoyment of handling games along with the social aspect of refereeing were the contributory factors in his continued involvement. Elleray (2000) refereed in order to remain actively involved in the game and considered the abuse he received to be insignificant 'when viewed against the great moments and friendships' (p. 287). Lack of further ambition was the deciding factor behind his retirement as he no longer craved the thrill and excitement of the job. Poll (2007) initially placed great weight on the challenge of refereeing before he progressed up the ladder and his continued involvement became influenced by the opportunity to be closer to the action in big games, his success further fostering his ambition. In addition to these recollections, Pitchford (2005) examined the responses of over 2000 referees about their overall experience. The study found that in relation to motivation, over $90 \%$ of the referees cited the intrinsic factors of enjoyment or involvement with football as their main motives for continued involvement. This contrasts with less than 5\% who cited finance as the decisive factor. Pitchford's findings can now be supplemented by evidence derived from qualitative research and, in particular, from interviews conducted for the present study. Each of the themes discussed below are relevant to the overall problematic - namely, the extent to which and the reasons why referees remain committed to their ‘occupation'. 


\section{Findings and discussion}

\section{Job satisfaction}

From the interview data, the main factor that appears to ensure continued involvement in refereeing is the degree of enjoyment each referee is able to derive from his experiences and the level of satisfaction that accrues as a result. Of the twelve referees who were interviewed, ten reported a high level of satisfaction with their refereeing experiences whilst two officials who operate at the grassroots level of the game reported a current lack of enjoyment, prompting both of them to consider stopping refereeing in the near future. These figures appear to support Pitchford's (2005) quantitative findings that 90\% cite enjoyment or involvement with football as their main motivation. In addition, all twelve interviewees supported Yucel's (2012) findings that, for human-service employees, job satisfaction is one of the most important factors influencing continued involvement. All of the referees who reported a degree of job satisfaction said they would not be involved if they did not enjoy it.

Daniel (Level 1): 'Yeah the majority of it, I enjoy the involvement, I enjoy looking back as much as anything, satisfaction of a job well done'.

Furthermore, the two who were considering stopping in the next few years both reported a lack of enjoyment as the decisive factor.

Stephen (Level 5): 'I've stopped enjoying it, I'm kind of borderlining, just doing it purely for the money'... 'If I do not get promoted I'm going to find something else to do because I feel I'm not gaining anything from it so I don't enjoy that'. 
Andrew (Level 5): 'It is increasingly the case that there are some things in refereeing that I find difficult to relate to positively... to the point where I think next season might be my last one'.

Jackofsky (1984) stipulates that satisfaction derives from successful performance. It appears that those referees involved in the professional and semi-professional game identify with this source of satisfaction. Indeed, many also recognised a close link between poor performance and lack of enjoyment.

Craig (Level 2a): 'I think as I've progressed up, it's when you make a big decision and you get it wrong, you're disappointed in yourself'.

On the other hand, referees at the lower levels appeared to pay less attention to their own performance whilst the Premier League referee, having agreed that he does enjoy refereeing, highlighted the impact of performance-related stress, his self-critical nature and the 'mental torture' he puts himself through as dominant factors in any lack of enjoyment.

Support for Jackofsky’s (1984) findings was found in the recollections of referees in the professional and semi-professional game. Most of them associated their best memories with performance-related achievements. For three of them, this was their promotion to a higher level and for another four, it was related to the recognition they had received through the opportunity to officiate at a cup final, a higher level of football, or in a foreign country. The referees at the lower end of the ladder associated their best moments with opportunities to officiate at big stadia or alongside well-known officials even if in matches that were perceived as having little importance, such as charity or corporate games. Such opportunities appear to have had an aspirational influence on some of them by highlighting the opportunities that exist, particularly at the professional level. 
Joseph (Level 4): 'Doing games at stadiums like that [Football League] gives you the hunger to get higher'.

The satisfaction derived from successful performance appears to be intimately linked to definitions of job satisfaction as outlined by Locke (1976) as a pleasurable state that is based on one’s job being fulfilling or valued. This measure of satisfaction was ascertained by questions about the challenges and rewards that the referees feel they face and receive. The three officials at the highest level of the game all recognised the pressures and the importance of the games they officiate and that this contributes to their enjoyment.

Craig (Level 2a): 'Each game is challenging, and if you meet that challenge then it's certainly rewarding, you've kept 22 players happy, you've dealt with the crowd, you've dealt with the media pressure, so it's very rewarding but the challenges are greater'.

However, the Premier League referee indicated that he only felt rewarded to a certain extent. Believing that the challenge is greater than the rewards, he suggested that higher pay and increased backing from The FA and the media are needed. At this level, it appears that the importance of games and, by implication, the job itself exceeds the fulfilment one can receive from the rewards on offer.

Those not involved with the professional game but who experienced a degree of satisfaction from refereeing paid less attention to the importance of their job whilst nevertheless perceiving it to be fulfilling. This was highlighted by a Level 4 official involved with semiprofessional football who feels rewarded at that level but not challenged, 'sometimes I wish it was more of a challenge'. Despite the lack of challenge, however, the fulfilment this referee experiences as a result of refereeing is reflected in his willingness to remain at the same level for the rest of his career. 
By contrast, the two referees who indicated an intention to stop refereeing in the near future appear not to find refereeing fulfilling or to value the games that they referee. Although at either end of the age spectrum (21 and 61 respectively), each prioritised other commitments in their life, such as job or personal factors, with the younger official stating that he saw refereeing as 'a means to an end', his motives for involvement in different leagues varying from, 'I'm there as a spectator' to 'I think I do the kids leagues to, you know, help kids out, teach kids a lot'. The older official also emphasised that his commitment was centred on football rather than on the act of refereeing.

Andrew (Level 5): 'I feel like I've got a commitment to football'.

Both men expressed altruistic motives for refereeing. They recognise the importance of the role of the referee but neither links that to his own enjoyment. This impacts on the degree of personal fulfilment they can gain from remaining involved, thereby further supporting Locke’s (1976) understanding of job satisfaction and offering an insight into why these interviewees intend to stop refereeing.

\section{Sources of dissatisfaction}

An analysis of job dissatisfaction can be developed by reference to the work of Porter and Steers (1973) which identifies personal factors, job content, the immediate work environment, and organisation-wide factors as the four interrelated dimensions influencing job satisfaction and withdrawal behaviour. The two officials with thoughts of withdrawing from refereeing cited personal factors such as job (Stephen) and age (Andrew) but also issues related to the refereeing work environment and job content. For the older official, age and 
physical capability may have led to more negative attitudes on the part of players, leading in turn to greater dissatisfaction with his personal refereeing experience.

Andrew (Level 5): 'I do find it a bigger challenge to keep up with things'... 'If I cannot contribute at the level they [the players] expect then there certainly will be a natural frustration'...'The attitude of players has... become a part of the game that devalues my experience... to the point where I think my next season will be my last one'.

Despite not having any current intention to withdraw, a Level Four official had once thought 'I don't want to be a referee anymore' after being assaulted at the grassroots level of the game. Such immediate work environment issues lead to dissatisfaction and an intention to stop which also appears to be related to dissatisfaction with organisation-wide factors (Porter and Steers, 1973). These were reported by most participants. A referee who is involved at the professional level of the game and works closely with The FA feels that the Respect campaign introduced by The FA may work at the higher levels but that 'there's too much abuse in grassroots football' and that The FA has not 'clamped down on it enough'. This appears to have caused problems for referees involved at that level.

Craig (Level 2a): 'I think if I was still involved in grassroots football the enjoyment wouldn't be as great because I think that there's too much abuse on the sidelines'.

Andrew (Level 5): 'The attitude of players has not benefitted from Respect initiatives'.

There was a consensus amongst the participants that the abuse of match officials is now a major issue although it is also clear from previous research (Mason, 1981; Pitchford, 2005) that the problem is not new. As we have seen, Pitchford (2005) identified the treatment of officials by others as the biggest source of dissatisfaction. However, he dismissed the the 
media's emphasis on the significance of abuse. This was supported by one official who believes that the effects of poor experiences are exaggerated by the media.

Daniel (Level 1): 'I think they [poor experiences] are very well documented but I don't think they actually are the vast majority of the reasons why people drop out of refereeing'.

Nevertheless, the findings do lend support to McCoy's (2003) recommendation, in relation to the teaching profession, of the need for greater respect towards the profession.

Half of the referees interviewed feel let down by The FA. One interviewee who is currently employed by the Association suggests that the perception is that 'sometimes referees feel distanced from The FA as a whole. Definitely as The FA, we need to be more accessible'. This links directly to the comments of a Level Five official who believes that the structure of the organisation in relation to his refereeing experience is 'far too formal'. A lack of backing from the FA was reported by referees at all levels, including one from the Premier League who said, 'I think the FA could do a lot better than what they do' and that they 'need to back referees a lot more'. A Level Two official observed, 'I don't think we as referees get enough backing from The FA as a whole'. As regards experiences at the county level, one Level Four official said, 'I don't really feel that I've been supported at all'. With around half of the referees reporting general dissatisfaction with organisation-wide factors, the evidence appears to contradict Pitchford's (2005) findings that the majority of referees were largely satiasfied with The FA and County FAs. Organisational factors should be considered by the governing body as these can be seen to have contributed to five potential refereeing withdrawals from the representative sample of twelve current referees. 


\section{Age factors}

In relation to withdrawal from refereeing, the effect of age on continued involvement was emphasised by both Pitchford (2005) and The FA (2012). Harris and Adams’ (2007) findings in other occupations suggest that turnover patterns differ significantly by age group. This appears to be supported by our oldest participant (aged 61).. His intention to stop refereeing the following season was, in large part, due to the effects of his age on his physical capabilities. His age has also led him to recognise that there are personal issues in his life that need to be resolved. However, this was the only indication from the interview data that there is substance to Pitchford's (2005) claim that $70 \%$ of officials cite age as their reason for future withdrawal.

Nevertheless, a number of age-related sources of dissatisfaction were reported by older officials within the sample. This was the result of previous age discrimination laws highlighted in the literature ('Tribunal rules retired assistant referees were discriminated against', 2010) that had impacted upon the progression of officials.

Luke (Aged 50, Level 4): 'I feel that I've been held back because of my age'.

Michael (Aged 55, Level 5): 'I know I won't go any higher, I was told then, 'You're too old' [by The FA]'... 'I did feel let down by that'.

This issue is also relevant, albeit in a different form, to the experience of the Premier League official who is prevented from refereeing in European competitions due to not having been nominated to the FIFA list of officials before the age of thirty-five.

Nigel (Level 1): 'I can't get there because of my age'... 'I've been told I can't referee European league'... 'I did feel frustrated by that'... 'Has it affected me? No not really'. 
This referee is able to rationalise the circumstances in which he finds himself and accepts the age criteria that were in place at the time. As a result, he attributes his frustration to himself and his lack of earlier progression.

Other older officials have benefitted from the new discrimination laws that stipulate that officials can no longer be removed because of their age. A forty-six year old official indicated that, in the circumstances, it was a pleasant surprise that he had recently been promoted by The FA.

Neil (Level 3): 'I never ever thought about being on the Football League because of my age'... 'Age discrimination act thank you very much'... 'It allows us grey haired buggers to achieve'.

At the opposite end of the spectrum, existing literature has highlighted the issues faced by younger referees. As noted above, The FA (2012) provided statistical information that between 2007 and 2010, there had been a 579\% decrease in the number of officials aged twenty to twenty-four. One explanation for this drastic decrease was provided by the official who is also an employee of The FA.

Daniel (Level One): 'We train a lot of young referees aged between fourteen and eighteen and during that period of their lives they have a lot of social changes, move away to university, they find girlfriends, they find women, they find going out and that sort of thing... so that seems to be the main reason for, for the majority of dropouts I've experienced'.

Of the twelve referees interviewed, four were between the ages of twenty and twenty-four. All acknowledged the transition that they were facing and realised how this had the potential to negatively affect their involvement in refereeing. 
Stephen, a Level Five official with an intention to stop refereeing in the near future, highlighted other priorities as his reasons for not remaining involved and explained how he views refereeing in terms of the benefits associated with it.

Stephen (Level 5): ‘... just doing it purely for the money... and when I'm on a teacher's salary thirty quid I really couldn't care less about'... 'Refereeing has aided me to get where I have in the jobs I've applied for'.

However, although Dean, a twenty-two year old trainee teacher, emphasised a conflict of goals that have emerged in his life, he also reported some positives in terms of balancing his refereeing and career ambitions.

Dean (Level 4): 'At the moment, university comes first'... 'It does work well my teaching practice. I can finish at four o'clock and... go to a game in the evening'.

Peter, a twenty-four year old Level Three referee, who has recently qualified as a teacher, believes that commitment required at his level and in refereeing generally is such that 'something somewhere will have to give career wise'. Despite this, he belives that, for the time being, teaching and refereeing 'fit hand in hand really'.

This sample of young referees may not be generalizable to this entire age group of officials not least because these participants share similar career paths. The outlier in the sample was twenty-two year old Alasdair who has taken a full-time job in football administration. He feels that his other commitments clash with his desire to make it to the top of the refereeing ladder. He also highlighted the difference in commitment levels between the grassroots and semi-professional levels of the game (Level 5 to 4).

Alasdair (Level 5): 'The job comes first for me'.. '[At level 5] you have a lot more freedom'. 


\section{Commitment and involvement}

Saal et al (1995) define job commitment as an attachment to the organisation as a whole. Blau and Boal (1987) found that organisational commitment and job involvement are key predictors of turnover. Findings from the data support these claims as three of the four referees who have made it into the professional game have prioritised refereeing over other commitments and greater attachment, through contractual obligations and voluntary work, within the organisation. Evidence of job commitment and involvement is seen to increase higher up the refereeing ladder.

Craig (Level 2a): 'I left that job because they wouldn't come and go with me with my refereeing'.

Daniel (Level 1): 'You do need a large amount of commitment to sort of be at the level I'm at now'... '[I fit my] job around refereeing. I don't think I would necessarily be able to be in the position that I'm in today if I'd have carried on down the path of becoming a solicitor'.

This commitment peaks at the highest level of the game. The Premier League official is one of eighteen officials in the country working with a full-time contract, his contractual obligations meaning that he is heavily involved in guest speaking and training amongst other things.

By comparison, as demonstrated earlier, some referees at the lower levels who are required to give less commitment to refereeing are more inclined to express their intention to stop refereeing.

Joseph (Level 4): 'Since I have decided to be in the police force, it's asking, do I want to use my leave for refereeing?'...'It's time to get my career sorted out and put my refereeing on the backburner'. 
Alasdair (Level 5): 'I think if you get to level 4, the expectancy is you're an official before anything else... the job comes first for me'.

Stephen, a Level Five official with a strong inclination to withdraw, believes that his refereeing is currently 'a means to an end', but only until the start of the following season when he begins teaching. The only circumstance that would make him continue to referee is if he can realise his ambition to be promoted in the current season. To progress up the ladder, an official needs to display considerable commitment by prioritising refereeing above other interests or by finding a career that can be fitted around refereeing. This has been achieved by all five participants at Level Three and above. Further discussions concerning the ambitions of the participants can be compared with the autobiographical accounts of other professional referees (Elleray, 2004; Poll, 2007), allowing us to verify whether continued involvement and/or intention to stop refereeing are significantly influenced by personal ambition to reach the higher levels of the game.

\section{Ambition}

The autobiographical sources reveal that involvement and enjoyment in refereeing are largely determined by the challenge associated with the job (Taylor, 1978; Poll, 2007). This is supported by the data collected for the present study as each of the twelve referees expressed their preference for refereeing challenging games.

Stephen (Level 5): 'That's where I get my motivation from, if it's not a challenge, I'm bored'.

Daniel (Level 1): 'A real challenge to referee is what gives you that drive and ambition really because you want to have the satisfaction of having control, you want the buzz of having done well in a game that wasn't easy'. 
The best way for referees to challenge themselves is to embrace the competitive nature of the classification system and to referee at progressively higher levels of the game (Thomson, 1998). This is supported by Poll (2007), a former Premier League referee, who was influenced early in his career by the challenge; once this challenge was removed, he retired.

The impact of ambition and facing challenges that are highlighted in the literature was recognised by a majority of the participants, regardless of their level.

Peter (Level 3): 'I remain involved really, I've got high ambition drive to succeed and to progress my way through the ranks within refereeing'...'If I was told I was going to stick at the same level for forty years or twenty years I think I would struggle to do that'.

Craig (Level 2a): 'It's always nice to have something to look to achieve'...'It's that drive to wanting to achieve that keeps me going'... “I'm the sort of person who always likes the carrot dangling... [if not] it would be hard to remain motivated'.

The data suggests that the threshold for the need to achieve and progress through the ranks is Level One. Both officials who have achieved that status recognise their achievement in becoming 'one of the top seventy-five referees in the country' (Daniel, Level 1). As a result, a lack of further progression would not result in them withdrawing from refereeing in the future. However, the referee at Level Two A indicated that he would struggle if he was forced to remain at his current level for the rest of his refereeing career. Some referees at the lower levels also highlighted their ambition to aspire to referee at a higher level, whereas others identified barriers to their progression.

The first potential barrier is rooted in the organisational policies implemented by The FA. Craig (Level 2a): 'The FA seems to be completely different... I don't know how you can have a system which says if you do this, you get this but then doesn't deliver the end'. 
Neil (Level 3): 'As soon as you get over forty and you see referees coming through promoted to level three at the age of twenty-two, you definitely think someone's trying to paint a picture there of who they want as a level three'.

The main impact of organisational policies appears to be age-related. All of the older referees suggested that their ambitions are, to a certain degree, curtailed by their age and their lack of belief that they can achieve certain things in the time that they have left.

Michael (55 year old Level 5): 'At my age, I know I've got to the level... where I won't get any higher'.

Nigel (Level 1): 'I can't get there [the FIFA list of officials] because of my age'.

Alternative viewpoints were expressed by younger referees who claim to benefit from the current organisational policies. They have all, at one time, aspired to be involved in the professional game. This could be partially related to the professionalisation of refereeing in 2001 having created clearer pathways and opportunities for new and younger referees (Elleray, 2004).

Peter (24 year-old Level 3): 'I want to be involved in the professional game at some point'... 'I'd love to make it to the top'.

Alasdair (22 year-old Level 5): 'When I was younger, I wanted to fly, I wanted to make it to the top'.

Ambition is clearly a major factor in continued involvement. Whether this ambition is motivated by financial considerations must be addressed in relation to Pitchford's (2005) findings that only five per cent of referees believe finance is a decisive factor behind their continued involvement. 


\section{Money}

In this instance, the data from the present study supports Pitchford's (2005) findings. Only one referee placed great emphasis on the link between income and involvement. The others are clear that neither their ambition nor their continued involvement is dependent on money.

Luke (Level 4): 'I don't do it just for the money'.

However, it also appears that the referees recognise the financial rewards and benefits of refereeing at a higher level.

Nigel (Level 1): 'We get paid well for what we do'.

Craig (Level 2a): 'The money is good at our level'...'You have to be rewarded for what you do'.

Luke (Level 4): 'The money goes into a pot and it pays for a holiday at the end of the year'.

Perhaps surprisingly, the only participant to report a degree of dissatisfaction with the financial rewards was the Premier League referee, whose income from refereeing is the greatest of all the participants.

Nigel (Level 1): 'We should get paid more'.

He believes that, given the pressures that he faces from the media and the players, the challenge of refereeing at his level exceeds the rewards he receives. This dissatisfaction can be understood when compared with the attitudes of other participants, as he is the only one to derive his sole source of income from refereeing. For the others, refereeing provides a second income which is less likely to provoke a sense of dissatisfaction. 
As a factor behind continued involvement in refereeing, money was mentioned by only one official who also reported that he intended to stop refereeing in the near future. A causal relationship could be tentatively suggested between the two as a focus on finance may have a detrimental influence on one's enjoyment of refereeing and subsequently a negative impact on continued involvement. By comparison, the social support within refereeing has a major influence on continued involvement.

\section{Social support}

The social support reported by referees can be categorised in two ways. First, there is the support of friends and close colleagues.

Daniel (Level 1): 'You need that mutual support to... bounce experiences off each other to make sure that when you, when you do go through a bad experience... you've got somebody to talk to’.

Dean (Level 4): 'If you didn't have anyone to talk to, there would be a lot of down moments'... 'I knew from the people around me, I was good enough to referee so I gave it another go'.

The second type of social support is linked to the mentoring scheme currently operated by The FA and to advice from refereeing friends and colleagues. The latter supports DarlingHammond's findings in a teaching context that effective mentoring programmes can improve retention rates. Seventy-five per cent of Pitchford's (2005) respondents believed that access to a mentor would be valuable to their refereeing. The data produced here also revealed positive attitudes towards official FA mentoring and coaching amongst officials involved in the professional game as well as younger referees. 
Luke (Level 4): 'I feel the benefit of a coach is for someone who is younger'.

Three of the four officials involved in the professional game emphasised the importance of their coach's impact on their own career. Younger referees also reported their coach to be of great assistance.

Joseph (28 year-old Level 4): 'She talks to me after every game, I really, really value that support'.

Peter (24 year-old Level 3): 'The support I receive from The FA through the mentor is great'.

The two referees who reported negative feelings about the official mentoring and coaching schemes in use at County FAs and The FA trace these to the formalised nature of the relationship between themselves and the coach.

Stephen (Level 5): 'I think it's far too formal' ... 'I don't think I've had a coach or a mentor that I've actually used'...'I'm not speaking to some coach who, you know, supposedly is there for you when you don't really know them'.

Craig (Level 2a): 'It needs to be much more relaxed... far too formal... everything has to be done by the book... which shouldn't be in a coaching relationship'.

These observations suggest that The FA and County FAs could benefit from a collaborative approach that takes advantage of the informal nature of the social circles of which referees are already members. This would almost certainly promote the development and continued involvement of referees whilst allowing organisational policies and schemes to sit at the heart of a strong support network.

Craig (Level 2a): 'Personally I would rather not have a coach, I don't think he's that much of a help... there's things I can discuss with mates and I get the same advice if not better'. 
Alasdair (Level 5): 'He looked out for me informally'.

The foregoing discussion provides evidence that could be used to inform future directions in organisational policies relating to the retention of current referees.

\section{Conclusion}

Before summarising the achievements of this study, it is worth considering its limitations. First, the sample was relatively small. In addition, it may have suffered from the convenience sampling method employed. This may admittedly have led to a selection of a sample based on ease rather than one that could give consideration to a wider range of variables. For example, the sample did not contain any female officials or any referees at Levels Six or Seven who had not achieved promotion in their career. In addition, further studies in this area would benefit from longitudinal research which would allow for the assessment of referees' intentions, motives and satisfaction over time and further identify areas for concern in relation to the retention of referees. Future research could usefully consider the reasons why people become referees, which was not within the remit of this study, and consider the extent to which such factors may have later bearing on continued involvement/withdrawal. Finally, it might also be useful to compare research into service-based occupations with studies of other types of occupation and profession although we believe at this stage that the role of the referee can most easily be aligned with the former.

Despite these qualifications, the insider knowledge of the first author ensured good access to a relatively wide range of the target population and had a positive impact on the interview design. The collection of data presented no major difficulties due to the access, professional 
relationships and friendships that the researcher had with the selected sample. Furthermore, although the sample was relatively small, using qualitative methods, particularly interviews, as opposed to a large-scale survey allowed for more subtle findings, in certain respects, than resulted from Pitchford's (2005) study.

Our findings confirmed Pitchford's claim that enjoyment is a major source of satisfaction for referees. However, it was evident that the participants in this study were less sanguine than Pitchford's respondents about lack of respect for officials being a significant source of dissatisfaction. The importance of age factors was shown to be more complex than Pitchford's study indicated although this may be partially explained by reference to the introduction of age discrimination legislation since the earlier study was conducted. In addition to enjoyment, ambition and both facing and addressing challenges emerged as major determinants in remaining involved in refereeing. Like Pitchford, we argue that financial reward is not a major factor although it is worth reiterating that the official who expressed the view that he is not paid enough was the one who is currently paid most, reflecting the pressures on referees at the highest level of the game. We are also able to confirm Pitchford's emphasis on the importance of support and mentoring although we would argue that our interviews offered more nuanced insights into the types of support that are wanted and the ways in which these can best be secured.

Ultimately, this study suggests certain significant directions for organisations to follow in order to ensure the retention of referees. Above all, there is a need for greater collaboration and contact between the governing bodies and individual referees. This should include taking advantage of the informal nature of the social circles of which referees are already a part. More specifically, organisational policies focused on creating clear pathways that foster the 
ambition of current referees, regardless of their age, would almost certainly increase the

likelihood of higher retention rates

\section{Appendix}

\begin{tabular}{|c|c|c|c|c|c|c|}
\hline Name & Age & $\begin{array}{l}\text { Referee } \\
\text { level }\end{array}$ & Scholar level & Referee & Profession & *Family life \\
\hline Daniel & 31 & 1 & $\begin{array}{l}\text { Undergraduate } \\
\text { degree level }\end{array}$ & $\begin{array}{l}\text { Part-time } \\
\text { combined } \\
\text { with } \\
\text { profession } \\
\text { shown } \\
\text { adjacent. }\end{array}$ & $\begin{array}{l}\text { Referee } \\
\text { Development } \\
\text { Officer for } \\
\text { Manchester FA. } \\
\text { Nature of job allows } \\
\text { for increased } \\
\text { understanding and } \\
\text { flexibility in terms of } \\
\text { his own personal } \\
\text { refereeing. }\end{array}$ & $\begin{array}{l}\text { No family, } \\
\text { currently in a } \\
\text { long-term } \\
\text { relationship }\end{array}$ \\
\hline$\overline{\text { Nigel }}$ & 42 & 1 & $\begin{array}{l}\text { Currently } \\
\text { undertaking } \\
\text { professional } \\
\text { courses } \\
\text { accredited by } \\
\text { Universities as } \\
\text { part of an } \\
\text { opportunity } \\
\text { offered by his } \\
\text { employees. }\end{array}$ & Full-time & $\begin{array}{l}\text { Contractually } \\
\text { obliged by } \\
\text { Professional Game } \\
\text { Match Officials } \\
\text { Limited (PGMOL) }\end{array}$ & $\begin{array}{l}\text { Married with } \\
\text { children }\end{array}$ \\
\hline Craig & 29 & $2 a$ & $\begin{array}{l}\text { Post-16 } \\
\text { education. No } \\
\text { undergraduate } \\
\text { degree. }\end{array}$ & $\begin{array}{l}\text { Part-time } \\
\text { but } \\
\text { currently } \\
\text { his sole } \\
\text { occupation }\end{array}$ & $\begin{array}{l}\text { Unemployed to } \\
\text { allow for flexibility } \\
\text { and commitment } \\
\text { towards } \\
\text { progression up the } \\
\text { refereeing ladder. }\end{array}$ & $\begin{array}{l}\text { No family, } \\
\text { single }\end{array}$ \\
\hline Neil & 46 & 3 & $\begin{array}{l}\text { Post-16 } \\
\text { education. No } \\
\text { undergraduate } \\
\text { degree. }\end{array}$ & Part-time & $\begin{array}{l}\text { Manager for bus } \\
\text { transportation } \\
\text { company }\end{array}$ & $\begin{array}{l}\text { Married with } \\
\text { children }\end{array}$ \\
\hline Peter & 24 & 3 & $\begin{array}{l}\text { Undergraduate } \\
\text { degree leading } \\
\text { to Qualified } \\
\text { Teacher Status } \\
\text { in Primary } \\
\text { Education. }\end{array}$ & Part-time & $\begin{array}{l}\text { Qualified as } \\
\text { Teacher }\end{array}$ & $\begin{array}{l}\text { No family, } \\
\text { currently in a } \\
\text { long-term } \\
\text { relationship. }\end{array}$ \\
\hline Dean & 22 & 4 & $\begin{array}{l}\text { Undergraduate } \\
\text { degree leading }\end{array}$ & Part-time & Trainee teacher & $\begin{array}{l}\text { No family, } \\
\text { single. }\end{array}$ \\
\hline
\end{tabular}




\begin{tabular}{|c|c|c|c|c|c|c|}
\hline & & & $\begin{array}{l}\text { to Qualified } \\
\text { Teacher Status } \\
\text { in Primary } \\
\text { Education. }\end{array}$ & & & \\
\hline Joseph & 28 & 4 & $\begin{array}{l}\text { Undergraduate } \\
\text { degree level }\end{array}$ & Part-time & $\begin{array}{l}\text { Pursuing job in } \\
\text { police force. } \\
\text { Currently a Police } \\
\text { Community Support } \\
\text { Officer. His desire } \\
\text { to follow this career } \\
\text { path may negatively } \\
\text { impact upon } \\
\text { refereeing } \\
\text { progression }\end{array}$ & $\begin{array}{l}\text { No family, } \\
\text { currently in a } \\
\text { long-term } \\
\text { relationship }\end{array}$ \\
\hline Luke & 50 & 4 & $?$ & Part-time & Delivery driver & $\begin{array}{l}\text { Married with } \\
\text { children }\end{array}$ \\
\hline Alasdair & 22 & 5 & $\begin{array}{l}\text { Undergraduate } \\
\text { degree level }\end{array}$ & Part-time & $\begin{array}{l}\text { Full-time job in } \\
\text { football } \\
\text { administration }\end{array}$ & $\begin{array}{l}\text { No family, } \\
\text { single. }\end{array}$ \\
\hline Andrew & 61 & 5 & $?$ & Part-time & $\begin{array}{l}\text { Construction } \\
\text { industry worker }\end{array}$ & $\begin{array}{l}\text { Divorced, } \\
\text { with children }\end{array}$ \\
\hline Michael & 55 & 5 & $?$ & Part-time & Unemployed & $\begin{array}{l}\text { Married with } \\
\text { children }\end{array}$ \\
\hline Stephen & 21 & 5 & $\begin{array}{l}\text { Undergraduate } \\
\text { degree leading } \\
\text { to Qualified } \\
\text { Teacher Status } \\
\text { in Primary } \\
\text { Education. }\end{array}$ & Part-time & Teacher & $\begin{array}{l}\text { No family, } \\
\text { single }\end{array}$ \\
\hline
\end{tabular}

\section{References}

Atkinson, J. (1958). Motives in Fantasy, Action and Society. New York: D. Von. Nostrand.

Bishay, A. (1996). Teacher Motivation and Job Satisfaction: A Study Employing the

Experience Sampling Method. Journal of Undergraduate Sciences, 3 (Fall), 147-154.

Blanchard, I. (2010). Review of Referee Data (2007-2010). Private correspondence.

Blau, G. and Boal, K. (1987). Conceptualising how Job Involvement and Organisational

Commitment Affect Turnover and Absenteeism. Academy of Management Review, 12 (2),

288-300. 
Booth, K. (2002). The Father of Modern Sport: The Life and Times of Charles W Alcock. Manchester: The Parrs Wood Press.

Boon, G (Ed.) (1998). Deloitte and Touche Annual Review of Football Finance 1996-97 Season. Manchester: Deloitte and Touche.

Boon, G (Ed.) (1999). Deloitte and Touche Annual Review of Football Finance 1997-98 Season. Manchester: Deloitte and Touche.

Cheloha, R and Farr, J. (1980). Absenteeism, Job Involvement and Job Satisfaction in an Organisational Setting. Journal of Applied Psychology, 65 (4), 467-473.

Colwell, S. (2000). The 'letter' and the 'spirit': Football laws and refereeing in the twentyfirst century. Soccer and Society, 1 (1), 201-214.

Cooper-Hakim, A. and Viswesvaran, C. (2005). The Construct of Work Commitment: Testing an Integrative framework. Psychological Bulletin, 131 (2), 241-259.

Darling-Hammond, L. (2003). Keeping Good Teachers. Educational Leadership, 60 (8), 613.

Davis, J. and Wilson, S. (2000). Principals’ Efforts to Empower Teachers. Effects on Teacher Motivation and Job Satisfaction and Stress. The Clearing House, 73 (6), 349-353.

Dunning, E. and Sheard, K. (1979). Barbarians, Gentlemen and Players: A Sociological Study of the Development of Rugby Football. Oxford: Martin Robertson. Elleray, D (2004). The Man in the Middle. London: Time Warner Books FIFA (2012). The Organisation. [online] Available at: >http://www.fifa.com/aboutfifa/organisation/index.html< [Accessed 10 December 2012] 
Harris, D. and Adams, S. (2007). Understanding the Level and Causes of Teacher Turnover: A Comparison with Other Professions. Economics of Education Review, 26 (3), 325-337. Hulin, C. (1966). Job Satisfaction and turnover in a female clerical population, Journal of Applied Psychology. 50 (4), 280-285.

Hulin, C. (1968). Effects of Changes in Job Satisfaction Levels on Employee Turnover. Journal of Applied Psychology, 52 (2), 122-126.

Jackofsky, E. (1984). Turnover and Job Performance: An Integrated Process Model. Academy of Management Review, 19 (1), p. 51-89.

Klassen, R. and Anderson, C. (2009). How Times Change: Secondary Teachers`Job Satisfaction and Dissatisfaction in 1962 and 2007. British Educational Research Journal, 35 (5), 745-759.

Keigher, A. (2010). Teacher Attrition and Mobility: Results from the 2008-09 teacher followup survey. Washington DC: National Center for Education Statistics. [NCES 2010 - 353].

Locke, E. (1976). The Nature and Causes of Job Satisfaction. In M. Dunnette, (Ed.), Handbook of Industrial and Organisational Psychology (pp. 1297-1340). Chicago: Rand McNally

Mangan, J.A. and Hickey, C. (2008). Keeping Control: Refereeing the Game. Soccer and Society, 4 (5), 727-749.

Mason, T. (1981). Association Football and English Society 1863-1915. Brighton: Harvester. McCoy, L. (2003). It's a Hard Job: A Study of Novice Teacher's Perspectives on why Teachers Leave the Profession.Current Issues in Education, 6 (7) [online]. Available at: >http://cie.ed.asu.edu/volume6/number7/< [Accessed 13 December 2012] 
Mor Barak, M., Nissly, J. and Levin, A. (2001). Antecedents to retention and turnover among child welfare, social work and other human service employees: What can we learn from past research? A review and meta-analysis. Social Science Review, 75 (4), 625-661.

Mowday, R., Steers, R. and Porter, L. (1979). The Measurement of Organisational Commitment. Journal of Vocational Behaviour, 14 (2), 224-247.

Pitchford, A. (2005). Referee Training and Development in England: A Report for The Football Association. Unpublished MSc thesis, Gloucester: University of Gloucestershire. Poll, G. (2008). Seeing Red. London: HarperCollins.

Porter, L. and Steers, R. (1973). Organisational Work and Personal Factors in Employee Turnover and Absenteeism. Psychology Bulletin, 80 (2), 151-176.

Rice, J., LaVergne, D. and Gartin, S. (2011). Agricultural Teacher Perceptions of School Components as Motivational Factors to Discontinue Teaching. Journal of Career and Technical Education, 26 (2) [online] Available at: >http://scholar.lib.vt.edu/ejournals/JCTE/v26n2/rice.html< [Accessed 13 December 2012] Saal, F. and Knight, P. (1995). Industrial/Organisational Psychology. Science and Practice. Belmont, CAL: Wadsworth.

Seddon, P. J. (1995). A Football Compendium: A Comprehensive Guide to the Literature of Association Football. London: British Library Publishing Division.

Steers, R. and Black, J. (1994). Organisational Behaviour. New York: Harper Collins. Taylor, J. (1978). Soccer Refereeing: Jack Taylor: A Personal View. London: Faber and Faber. 
The Football Association. (2012). Respect - Four Years On. [online] Available at:

>http://www.thefa.com/News/my-football/2012/jul/four-years-on.aspx < [Accessed 11

December 2012]

The Referees’ Association. (2012 a). Background and Formation. [online] Available at:

$>$ http://www.refereesassociation.co.uk/index.asp?page=become-a-referee $<$. [Accessed 10

December 2012]

The Referees’ Association. (2012 b). Background and Formation. [online] Available at:

>http://www.refereesassociation.co.uk/index.asp?page=ra-history<. [Accessed 10 December 2012]

Thomson, G (1998). The Man in Black: A History of the Football Referee. London: Prion Books.

Vroom, V. (1964). Work and Motivation. New York: Wiley

Winter, J. (2006). Who's the B*****d in the Black: Confessions of a Premiership Referee. London: Ebury Press

Yucel, I (2012). Examining the Relationships among Job Satisfaction, Organisational Commitment and Turnover Intention: An Empirical Study. International Journal of Business Management, 7 (20), 44-58.

\section{Newspaper articles}

‘Assistant Referee Steven Craven Quits After Abuse Following Celtic Row’, Guardian (2010) [online] Available at: > http://www.guardian.co.uk/football/2010/oct/25/assistanreferee-quits-celtic-dundee-united< [Accessed 11 December 2012] 
‘Chesham United match abandoned after striker “punches” referee’. Observer (2011)[online] Available at: >http://www.guardian.co.uk/football/2011/oct/15/chesham-match-abandonedpunches-referee < [Accessed 11 December 2012]

'Rain of Abuse Stops Play: One Persecuted Referee’s Account', Observer (2005) [online] Available at: >http://www.guardian.co.uk/uk/2005/jan/30/football.theobserver < [Accessed 11 December 2012]

'Referee Gets Death Threats Over Controversial Gerrard Penalty’, Guardian (2008) [online] Available at:

>http://www.guardian.co.uk/football/http://www.guardian.co.uk/football/2008/nov/20/liverpo ol-atleticomadrid2008/nov/20/liverpool-atleticomadrid< [Accessed 11 December 2012]

'Tribunal rules retired assistant referees were discriminated against', Gurdian (2010) [online] Available at: > http://www.guardian.co.uk/football/2010/apr/15/retired-assistant-referees-agediscrimination< [Accessed 11 December 2012] 